УДК 25

\title{
Increasing Scope of Application of Multi-Rope Hoists with Friction Pulleys in Small-Depth Mine Shafts
}

\author{
Dmitrii S. Naumov*a, \\ Sergei S. Naumov and Oksana S. Golovataya ${ }^{b}$ \\ ${ }^{a}$ LLC NTC Geotech Prombezopasnost \\ Saint-Petersburg, Russian Federation \\ bPitirim Sorokin Syktyvkar State University \\ Syktyvkar, Russian Federation
}

Received 12.01.2019, received in revised form 01.10.2019, accepted 21.02.2020

Abstract. Possible ways to increase the scope of application of multi-rope friction hoists are considered. Theoretical calculations are given.

Keywords: guide sheave, hoist (head) rope, skips.

Citation: Naumov D.S., Naumov S.S., Golovataya O.S. Increasing scope of application of multi-rope hoists with friction pulleys in small-depth mine shafts, J. Sib. Fed. Univ. Eng. \& Technol., 2020, 13(2), 144-155. DOI: 10.17516/1999-494X-0210

\section{Расширение области применения}

\section{многоканатных подъемных машин со шкивами трения на шахтных стволах малой глубины}

\author{
Д.С. Наумов ${ }^{\text {a }, ~ С . С . ~ Н а у м о в, ~ О . С . ~ Г о л о в а т а я ~}{ }^{0}$ \\ ${ }^{a} О О О$ «НЭЦ «Геотех Промбезопасность» \\ Российская Федераиия, Санкт-Петербург \\ ${ }^{6}$ Сыктывккарский государственный университет \\ имени Питирима Сорокина \\ Российская Федераиия, Сыктывкар
}

Аннотация. Рассматриваются возможности расширения области применения многоканатных шахтных подъемных машин. Приводятся теоретические расчеты.

(c) Siberian Federal University. All rights reserved

This work is licensed under a Creative Commons Attribution-NonCommercial 4.0 International License (CC BY-NC 4.0).

* Corresponding author E-mail address: kirovsk@mail.ru,nds101@mail.ru 
Ключевые слова: канатоведущий шкив, тяговый (головной) канат, подъемные сосуды.

Цитирование: Наумов, Д.С. Расширение области применения многоканатных подъемных машин со шкивами трения на шахтных стволах малой глубины / Д.С. Наумов, С.С. Наумов, О.С. Головатая // Журн. Сиб. федер. ун-та. Техника и технологии, 2020. 13(2). C. 144-155. DOI: 10.17516/1999-494X-0210

Hoists in multi-floor residential and industrial buildings and mine winders often use a friction pulley as a traction body. In mine hoisting machines multi-rope friction hoists are generally used that include a guide sheave and a deflecting pulley mounted on a tower crane. The scheme of such a machine is shown in Fig. 1.

At present, the task to increase performance of a multi-rope hoist remains relevant. To increase productivity by increasing the load capacity of skips is energy- and cost-effective. However, in this case the critical circumferential force $\left(\mathrm{F}_{n}\right)$ transmitted to the rope is limited:

- lifting a load:

$$
F_{l}=S_{1}-S_{2}=S_{2} \cdot\left(e^{\mu \alpha}-1\right),
$$

- lowering a load:

$$
F_{d}=S_{1}-S_{2}=S_{2} \cdot\left(1-e^{\mu \alpha}\right),
$$

where $S_{1}$-tension of the ascending (entering) branch; $S_{2}$ - tension of the descending (slacking) branch; $\mu$-coefficient of the rope friction on the liner of the guide sheave; $\alpha$-angle of grasping of guide sheave by a rope, rad.

From the analysis of expressions (1) and (2), it appears that the hoisting ability of the hoist with a friction pulley can be increased:

- by using liners with a high coefficient of friction;

- by increasing angle of grasping of the guide sheave;

- by increasing tension of both branches of the unit.
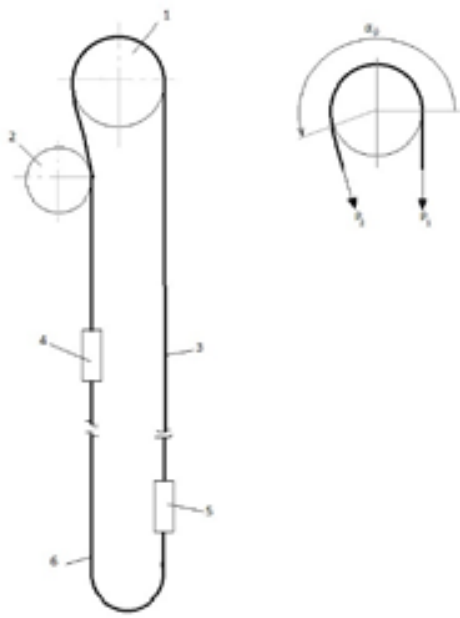

Fig. 1. The general view of a hoisting machine with a friction pulley: 1 - guide sheave; 2 - deflecting pulley; 3 hoist (head) rope; 4, 5 - skips or cages; 6 - balance rope 
Increasing hoisting capacity by raising the friction coefficient of the rope along the liner of the pulley should be approached with some caution, as with a high coefficient of friction it is possible to create situations with broken ropes. With an increase in the grasping angle of the guide sheave by a rope, the bending stresses in them also increase, which leads to decreasing service life of the ropes and complex services during operation.

When considering the possibility of increasing the hoisting capacity of the winder with a friction pulley due to increasing tension of the branches, it is generally considered to specify installations with maximum and minimum possible depths of application. The maximum possible hoisting depth is determined on the basis of safety margin of the rope $[1,2]$ :

$$
H_{\max }=\frac{\sigma}{\gamma_{0}} \cdot \frac{z_{0}-z_{\min }}{z_{0} \cdot z_{\min }}
$$

where $\sigma$ - ultimate strength of a rope, $\mathrm{MPa} ; Z_{0}$ - necessary static safety margin of a rope (ratio of tensile strength of the rope to maximum static tension in the calculated cross section), based on safety requirements; $Z_{\min }$ - minimum allowable safety margin; $\gamma_{0}$ - fictitious rope density, $\mathrm{MPa} / \mathrm{m}$.

The verification of the condition of permissible pressure of the ropes on the liner of the guide sheave is performed according to formula [1]:

$$
\frac{S_{1}+S_{2}}{n \cdot d_{r} \cdot D_{S}} \leq[S]
$$

where $S_{1}$ and $S_{2}$ - static tensions of branches of the ropes respectively at the points of entering and slacking directly at the guide or beam sheave; $D_{s}$ - diameter of guide sheave; $d_{r}$-diameter of the rope; $n$ - number of ropes.

The analysis of formulas (3) and (4) allows concluding that the maximum hoisting height can be limited only by strength factors of the rope. So, the standards of specific pressure can be followed by making a pulley of required diameter. At that, the condition of non-slip of the ropes is ensured by reducing maximum value of the coefficient of static tensions with increasing of depth. At present, the maximum possible theoretical depth of ascending is $2000 \mathrm{~m}$ for multi-rope hoists with closed ropes [1].

A minimum allowable hoisting height for a multi-rope hoist is such a hoisting height when, in the case of maximum use of the rope load capacity, the actual and allowable values of the static tension coefficients become equal. If this value is exceeded, the rope will begin to slip on the block [2]. In practice, for multi-rope installations of small depths, a method of artificially increasing weight of skips or ropes is used to ensure non-slip of the rope, however, this reduces efficiency of hoisting. On the one hand, increasing weight of skips increases the scope of application of multi-rope hoisting at depth less than $600 \mathrm{~m}$, on the other hand, it leads to an unreasonable significant increase in the material consumption of the entire machine and, as a result, increase of engine power and electric power consumption.

The next safety solution for the slip resistance condition is to increase static tension of the ropes. In general, the safety factor is determined by the formula:

$$
\sigma=\frac{S_{2} \cdot\left(e^{f \alpha}-1\right)}{S_{1}-S_{2}}
$$


At that, the static safety factor for slip resistance of the ropes must satisfy the condition:

$$
\sigma_{s t}=\frac{S_{s t 2} \cdot\left(e^{f \alpha}-1\right)}{S_{s t 1}-S_{s t 2}}>1,75
$$

where $S_{s t 2}, S_{s t l}$ - respectively the static tension of the slacking and entering branches, defined by the formula:

$$
S_{s t}=\left(m_{1}+m_{2}\right) \cdot g+\left(p \cdot n \cdot H+m_{w}\right) \cdot g,
$$

where $m_{1}$ - skip mass; $m_{2}$ - mass of lifted load; $g$ - gravitational acceleration; $p$ - specific weight of the head (hoist) rope; $n$ - a number of head ropes; $H$ - height of the hanging line; $m_{w}$ - mass of weights.

The dynamic safety factor for slip resistance of the ropes on the pulley must satisfy the condition:

$$
\sigma_{d}=\frac{S_{d 2} \cdot\left(e^{f \alpha}-1\right)}{S_{d 1}-S_{d 2}}>1.25
$$

Dynamic tension of the ropes used for entering and slacking branches are determined respectively by the formulas:

$$
\begin{aligned}
& S_{d 1}=S_{s t 1}+m_{3} \cdot a, \\
& S_{d 2}=S_{s t 2}-m_{4} \cdot a,
\end{aligned}
$$

where $\mathrm{m}_{3}$ - total mass of the load of the entering branch; $\mathrm{m}_{4}$ - total mass of the load of the slacking branch; a - acceleration (deceleration).

The analysis of formulas (5-10) shows that the basic value for determining safety factor is static tension of the ropes. To create additional effort, it is proposed to install a tensioning device that creates tension in branches of the rope and, thus, makes it possible to refuse weighted skips. The formula for determining static tension of the ropes will take the form:

$$
S_{s t}=\left(m_{1}+m_{2}\right) \cdot g+\left(p \cdot n \cdot H+m_{w}\right) \cdot g+\Delta S+m_{t} \cdot a,
$$

where $\Delta \mathrm{S}$ - additional tension created by the tensioning device, $m_{t}$ - reduced mass of the tensioning device.

The idea of tensioning devices in hoists with a friction pulley was first expressed by Prof. A.E. Trop. The work [6] contained a theoretical rationale of the load capacity depending on the lifting height, based on the static hoisting (excluding dynamic loads), to determine the weight of the tensioning device. The expediency of tensioning devices in inclined deep-pit hoists is indicated in [7].

A multi-rope hoist with a tensioning device has a number of advantages in comparison to hoists with weighted skips. The mode of breaking the lifting load is the most dangerous during the descentascent process. The mass of the lifted load is calculated by the formula:

$$
m_{2}=\frac{m_{\Sigma} \cdot\left[(g+a) \cdot\left(1-e^{-f \alpha}\right)-2 a \cdot \sigma\right]}{(g+a) \cdot\left(\sigma-1+e^{-f \alpha}\right)}
$$

where $m_{\Sigma}-$ total mass of entering/slacking branches, equal in statically balanced hoists; $\sigma$-dynamic safety coefficient; $\alpha$ - angle of the pulley circumference; $f$ - friction coefficient.

$$
-147 \text { - }
$$


When a skip is weighted by a certain amount $\Delta \mathrm{m}_{\Sigma}$, the mass of the lifted load $\left(\mathrm{m}_{2 \mathrm{w}}\right)$ is increased by $\Delta \mathrm{m}_{2}$ :

$$
\begin{aligned}
& m_{2 w}=m_{2}+\Delta m_{2}= \\
& =\frac{m_{\Sigma} \cdot\left[(g+a) \cdot\left(1-e^{-f \alpha}\right)-2 a \cdot \sigma\right]}{(g+a) \cdot\left(\sigma-1+e^{-f \alpha}\right)}+\frac{\Delta m_{\Sigma} \cdot\left[(g+a) \cdot\left(1-e^{-f \alpha}\right)-2 a \cdot \sigma .\right.}{(g+a) \cdot\left(\sigma-1+e^{-f \alpha}\right)} .
\end{aligned}
$$

Thus, from the analysis of equation (13) it follows that the increment of the load capacity is directly proportional to the weighting and inversely proportional to deceleration. As deceleration increases, the fraction numerator decreases, and the denominator increases, therefore, the fraction value and the increment value of the load capacity decrease.

For a hoist with a tensioning device, the tension of entering $S_{1}$ and slacking $S_{2}$ branches is increased by $\Delta \mathrm{S}$ due to the force generated by the tensioner, which, in terms of increment of payload $\Delta \mathrm{m}_{2}$, will be:

$$
\Delta m_{2}=\frac{\Delta S \cdot\left(1-e^{-f \alpha}\right)}{(g+a) \cdot\left(\sigma-1+e^{-f \alpha}\right)} .
$$

The analysis of expression (14) showed that during deceleration growth, the lifting capacity of the hoist decreases less than in hoists with weighted skips, and the use of tensioning devices is more effective than weighting of skips. In addition, hoists with a tensioning device are more efficient in terms of hoisting dynamics. The use of tensioning devices allows operating hoists at smaller depths as well.

According to equation (13), the increment of load capacity is directly proportional to the increment of the mass of the branches and inversely to deceleration and also depends on the coefficient of friction of the ropes along the liner of the guide sheave and angle of grasping of the guide sheave. The dependence on the hoist deceleration, the friction coefficient and grasping angle can be expressed by a constant coefficient A - load coefficient when the hoist is loaded by inertial loads. In this case, the load capacity of the hoist, expressed by means of the mass of the ropes, is described by the equation:

$$
m_{2}=A \cdot p \cdot n \cdot H
$$

where $\mathrm{p}$ - specific weight of head (hoist) rope; $\mathrm{n}-\mathrm{a}$ number of head ropes; $\mathrm{H}$ - height of the rope hanging.

There is a certain height of the rope hanging where the tensile stresses in the ropes reach maximum permissible values, and the load capacity of the hoist reaches the highest value. When reducing the hanging height, the load capacity decreases, and the tension of the branches and the tension in the ropes also decrease, i.e. the ropes are underloaded and have an excessive margin of safety. To ensure the greatest load capacity, the missing tension of the ropes can be compensated for by loading the branches with additional forces created by the tensioning device, Fig. 2. If the additional tension of the branches is expressed by means of the mass of the ropes, then the increment of the load capacity will be:

$$
\Delta m_{2}=B \cdot p \cdot n \cdot X
$$

where $\mathrm{B}$ - load factor when loading the branches without inertia forces generated by the tensioning device; $\mathrm{X}$ - height of part of the ropes compensated by additional forces generated by the tensioning device. In this case, the total load capacity $m_{2 t}$ of the hoist with tensioning device is as follows:

$$
m_{2 t}=m_{2}+\Delta m_{2}=(A \cdot H+B \cdot X) \cdot p \cdot n
$$




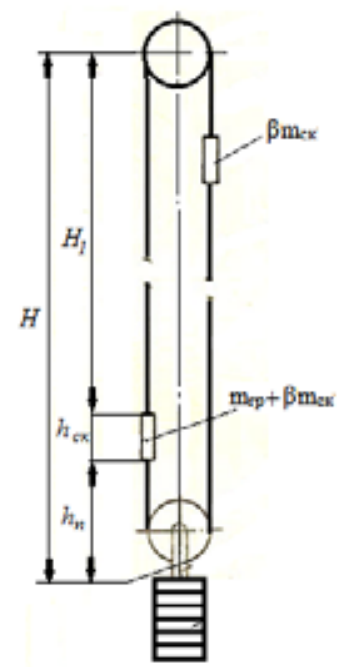

Fig. 2. The diagram of a statically balanced lifting system with a friction pulley and a tensioning device

Neglecting the inertia of the tension pulleys, the value of the coefficients of proportionality A and $\mathrm{B}$ is determined by the following assumptions:

- the hoist is statically balanced;

- the criterion of safety of work of hoists with friction pulleys is the value of dynamic safety coefficient, which in all cases is taken not less than 1.25 ;

- the most dangerous mode of operation of the hoist - deceleration at descending of load;

- dynamic safety factor is determined by the formula (8).

For a two-skip hoist with a tension device, the total tension of the slacking (descending) branch will be:

$$
\begin{aligned}
& S_{2}=\left(m_{2 t} \cdot(1+\beta)-k_{1} \cdot m_{2 t}+p \cdot n \cdot H\right) \cdot g+ \\
& +\left(m_{2 t} \cdot(1+\beta)+p \cdot n \cdot H\right) \cdot a+p \cdot n \cdot X \cdot g,
\end{aligned}
$$

where $\beta$ - tare coefficient; $k_{1}$ - coefficient of resistance to the movement of the descending branch; $g-$ gravitational acceleration; $a$ - deceleration of the hoist during descending of load.

The total tension of the entering (ascending) branch will be:

$$
\left.S_{1}=\left(\beta \cdot m_{2 t}+k_{2} \cdot m_{2 t}\right)+p \cdot n \cdot H+p \cdot n \cdot X\right) \cdot g-\left(\beta \cdot m_{2 t}+p \cdot n \cdot H\right) \cdot a,
$$

where $k_{2}$ - coefficient of resistance to the movement of the ascending branch.

Sum it up so far, we obtain the formulas for calculating coefficients $A$ and $B$ :

$$
\begin{aligned}
& A=\frac{(g+a) \cdot\left(1-e^{-f \alpha}\right)-2 \cdot a \cdot \sigma}{(g-k \cdot g+a) \cdot \sigma-\left(g-k_{1}+a\right) \cdot\left(1-e^{-f \alpha}\right)-\beta \cdot\left[(g+a) \cdot\left(1-e^{-f \alpha}\right)-2 a \sigma\right]}, \\
& B=\frac{g \cdot\left(1-e^{-f \alpha}\right)}{(g-k \cdot g+a) \cdot \sigma-\left(g-k_{1}+a\right) \cdot\left(1-e^{-f \alpha}\right)-\beta \cdot\left[(g+a) \cdot\left(1-e^{-f \alpha}\right)-2 a \sigma\right]},
\end{aligned}
$$

where $k$ - total coefficient of resistance to movement of the branches.

When studying the influence of the rope strength to the load capacity of the hoist, it is necessary to take into account that $\mathrm{A}$ and $\mathrm{B}$ coefficients depend on deceleration values of the hoist, on the tare 
and safety factors for slip resistance, as well as on the friction coefficient and the grasping angle, in proportion to which the load capacity changes, consequently, the greatest load capacity is achieved depending on their value at different heights of the hanging line of the ropes.

The static safety margin of the ropes $Z$ is equal to:

$$
Z=\frac{S_{b r} \cdot n}{S_{\max }}
$$

where $n$-a number of ropes; $S_{b r}$ - total breaking strength of all wires of the rope, $\mathrm{H} ; S_{\max }$ - maximum static load of load branch, $\mathrm{H}$.

Maximum static load capacity is determined by the formula:

$$
S_{\max }=\left(m_{2 t} \cdot(\beta+1)+p \cdot n \cdot(H+X)\right) \cdot g .
$$

The height of the part of the ropes $X$, compensated by additional forces of tensioning devices, is defined as difference between permissible lifting height $H_{\max }$ with the greatest payload under the condition of slip resistance and actual lifting height $\mathrm{H}$ :

$$
X=H_{\max }-H .
$$

After appropriate transformations, the formula for determining the permissible lifting height of a multi-rope hoist with a tension device will take the form:

$$
H_{\max }=\frac{L_{b r}}{K-(1+\beta) \cdot(A \cdot H+B \cdot X)},
$$

where $L_{b r}$ - critical breaking length of the rope, defined by the formula:

$$
L_{b r}=\frac{S_{b r}}{p \cdot g}
$$

The maximum load at permissible height of the rope is determined by the expressions:

- with a constant safety margin of the ropes:

$$
m_{A}=A \cdot p \cdot n \cdot H_{A},
$$

- with a variable safety margin of the ropes:

$$
m_{A}^{\prime}=A \cdot p \cdot n \cdot H_{A}^{\prime} \text {. }
$$

The analysis of formulas (20) and (21) showed that $\mathrm{A}<\mathrm{B}$. This fact means that the terminal load grows slower in case of the increment in the height of rope hanging than when compensating for the missing load of the branches with forces generated by a tensioning device. Consequently, in installations with a tensioner, the tension in the ropes will reach the maximum permissible values at compensating part of rope hanging with shorter length than permissible height $H_{\max }$.

Analyzing formula (24), we determined that under various operating conditions for hoists without tensioning devices where $X=0$, the actual hoisting height $H$ tends to the value of the permissible hoisting height $H_{\max }$. While for hoists with tensioning devices where the depth of ascending tends to zero, the value of $X$ tends to $H_{\max }$. Therefore, it is possible to assume the coincidence of the load 
capacity graphs under the condition of rope strength for the hoists without a tension device and with a tension device.

The load capacity as well as the permissible rope hanging height are determined uniquely for each hoist with specified parameters and will differ when they change. To clarify restrictions on the load capacity under the condition of permissible specific pressures on the liner of the guide sheave, we consider a hoist where the ropes are hung with the total weight of both branches creating pressure on the liner equal to the permissible one.

The total tension of both branches of the installation $S_{\Sigma}$ is determined by the formula:

$$
S_{\Sigma}=\left(m_{2} \cdot(2 \cdot \beta+1)+2 \cdot p \cdot n \cdot H\right) \cdot g .
$$

The specific pressure on the liner of the pulley will be:

$$
\gamma=\frac{S_{\Sigma}}{D_{s} \cdot d_{r} \cdot n}
$$

where $D_{s}$ - the diameter of guide sheave; $d_{r}$ - the diameter of the rope.

The ratio of the diameter of the rope to the diameter of the guide sheave $(\delta)$ is controlled by the safety rules and determined by the formula:

$$
\delta=\frac{D_{s}}{d_{r}}
$$

The ratio of the weight of a meter of rope to the square of its diameter $(\lambda)$ :

$$
\lambda=\frac{\delta \cdot \gamma}{d_{r}^{2}}
$$

The final equation of the load capacity of the hoist under the conditions of permissible pressure on the liner will take the form:

$$
m_{2}=\frac{2 \cdot\left(\frac{\delta \cdot \gamma}{Z \cdot \lambda}-H\right) \cdot p \cdot n}{1+2 \cdot \beta} .
$$

In the final equations of load capacity under the conditions, such as: slip resistance of the ropes, their strength and permissible specific pressures on the liner of the pulley, the load capacity of the installations with a friction pulley is represented as a dependent value on mass of a meter of the branch of the ropes. Equating the mass of a meter of ropes to one $(p \cdot n=1)$, it is possible to make some general graphs covering hoists by load capacity and lifting height from zero to the maximum possible values with constantly specified parameters, such as: safety factor for slip resistance, coefficient of tare, coefficient of cable friction on the liner of the pulley, angle of grasp of the guide sheave by ropes, resistance to movement of branches, deceleration of skips, strength of the ropes and the liner.

If we chart the load capacity, it is advisable to show the following example. To construct the diagram, we plot on abscissa - the lifting height, on ordinate - the load capacity of hoist.

We consider a hoist with a friction pulley and a tensioning device, equipped with the ropes of a similar design, having a temporal tensile strength $\sigma^{\circ}=1600 \mathrm{MPa}$, a breaking length of the rope $L_{b r}=18400 \mathrm{~m}$ and coefficient $\lambda=56.7 \cdot 10^{3} \mathrm{~kg} / \mathrm{cm}^{2}$, lifting skips with tare coefficients $\beta=0.5$. 
The following values were taken in calculations: deceleration during the descent of the load $a=1.5 \mathrm{~m} / \mathrm{sec}^{2}$; dynamic safety factor for slip resistance $\sigma_{d}=1.25$; movement resistance coefficients $k=0.15$ and $k_{l}=0.09$; coefficient of friction of the ropes on liner $\mu=0.25$; angle of grasp of guide sheave $\alpha=180^{\circ}$; specific permissible pressure on liner of the pulley $\gamma_{1}=2.5 \mathrm{MPa}$. According to the adopted main parameters of the hoist, the values of proportionality of the load capacity coefficients were calculated by the formulas (20), (21): $A=0.237$ and $B=0.697$.

The construction of load capacity diagrams (Fig. 3) is performed in the following sequence:

1. Take arbitrarily the values of coefficient $A$ :

- the values of permissible heights of rope hanging with a constant safety margin are found by formula (25);

- the maximum load capacities corresponding to the allowable heights are calculated by formulas (27, 28).

According to the calculated values (formula (27)) we construct graph 1 with safety margin of the rope $K=7$ and graph 2 with $K=4.5$. According to formula (28) we build graph 3 for a variable safety factor.

2. The value of the height of the ropes $-\mathrm{H}$ is given arbitrarily by formula (33), we build load capacity graph 4 under the conditions of permissible specific pressures on the liner of the pulley: $\gamma=2.5 \mathrm{MPa}$, and graph 5 with $\gamma=5.0 \mathrm{MPa}$.

3. The known value of coefficient of proportionality: $A=0.237$ and arbitrary values of rope hanging height $-H$ are given by formula (15). We build graph 6 for the load capacity of the hoist without a tension device.

4. The weightless ropes with the known values $L_{b r}, k, \beta$ and $B$ are given. We determine a conditional permissible height and, according to formula (17), we calculate the maximum load capacity of the installation under the condition of additional tension of the branches created by a tensioning device. The given position of the weightlessness of the ropes explains the position of a point corresponding to the greatest load capacity on ordinate of the installation with a tensioning device. It is the point "a". The second point "c" is defined as common for hoists with tensioning devices and without them. It is

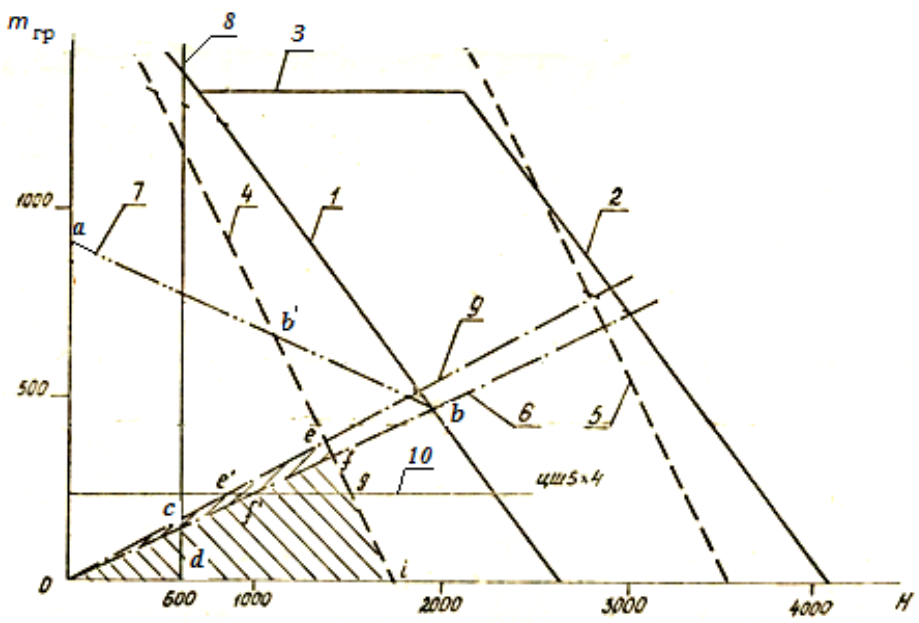

Fig. 3. Load capacity diagram of hoist at $a=1.5 \mathrm{~m} / \mathrm{sec}^{2}$ 
expressed by the intersection of graphs 6,1 and 2 . Connecting points a and $b$, we find graph 7 reflecting the load capacity under the condition of slip resistance of the ropes for hoists with tensioning devices.

Chart 8 is a line characterizing restriction of the use of multi-rope hoists without weighted skips at the depth less than $600 \mathrm{~m}$. To analyze the diagrams, it is advisable to construct additionally load capacity graph 9 with weighted skips: $\beta=1.0$ and $A=0.268$. The graph also reflects load capacity of installations with counterweights. It should be emphasized that in this case, the load capacity determined from the diagram corresponds to value $m_{2} / 2$.

The analysis of the obtained diagrams allows the following conclusions:

1. Operating hoists with friction pulleys are described by the area of the diagram, the perimeter of the area is determined by the lines drawn by means of "cfid" points, it is about $8 \%$ of the entire area of the diagram (Fig. 3). The use of weighted skips: $\beta=1.0$ expands the scope of application of hoists with friction pulleys slightly. According to the value described by the area of diagrams, the perimeter of which is determined by the lines drawn through "0egi" points, and the scope of application increases at decelerations $1.5 \mathrm{~m} / \mathrm{sec}^{2}$ by $9 \%$. For example, the machine with $5 \times 4$ flat-faced pulley (a horizontal line 10 ) is indicated. The calculations show that when deceleration is reduced to $0.5 \mathrm{~m} / \mathrm{sec}^{2}$ with weighted skips, the scope of application for hoists with friction pulleys does not exceed 30-35\% of the total area of possible application. Besides, round-strand ropes are exposed to a significant stretching up to $0.5 \%$, which makes it difficult, especially in case of a double skip ascent, to stop lifting skips at given loading and unloading points and also requires more attention to the leveling of the loads between the ropes.

2. The application of tensioning devices in hoists allows expanding the scope of application of hoists with friction pulleys by $2 \div 3$ times, especially at depths $600 \div 800 \mathrm{~m}$ or less. It appears from the diagram that the parameters of using of hoisting machines with friction pulleys and tensioning devices are determined by graph 4 (load capacity under the condition of permissible specific pressures on the liner of the guide sheave) and graph 7 (under the strength condition of the ropes when applying tensioning devices). The diagram area is described by "ab efgi0" points.

3. Further expansion of the hoists application scope with friction pulleys covering the entire area of the diagram at simultaneous growth of the load capacity can be achieved by using lining materials with a permissible specific pressure up to 5.0 $\mathrm{MPa}$.

It should be noted that the idea of using tensioning devices in hoists with a friction pulley has not been fully implemented until now. There are some real projects for the application of such devices. We consider, for example, a pulley as a tensioning station of a cargo drive which is located on terminal ropes with a load hung to it. Depending on the load capacity and height, the weighting mass of the tension station can reach tens or even hundreds of tons, the volume of tension load can be made of cast iron or steel $15 \div 20 \mathrm{~m}^{3}$, concrete or reinforced concrete $-50 \div 60 \mathrm{~m}^{3}$ and more. It can create additional difficulties in placing the load in the shaft. In this case, the reduction of material consumption can be achieved by using hydraulic tensioning devices. Figure 4 presents a general view of a hoist with a hydraulic drive of a tensioning device and a schematic diagram of a tensioning device protected by copyright certificate No. I02034I (USSR) [8].

The presented design of the tensioning device allows choosing elongation of ropes, resulting from residual deformation automatically by starting a hydraulic drive at the calculated force. As the ropes are drawn and the sloping part of wedges is used, an additional removable liner is installed, during the installation period the tensioning device is fixed by tightening bolts. 


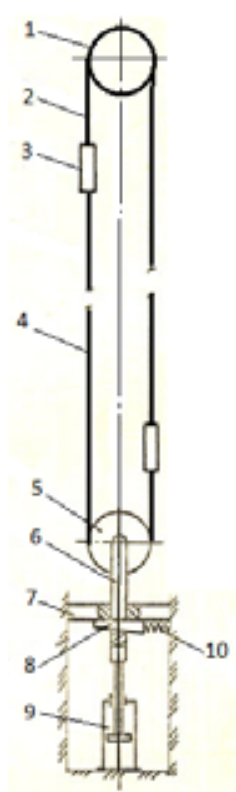

Fig. 4. The general view of hoist with a tensioning device and a hydraulic drive: 1 - guide sheave; 2 - head (hoist) rope; 3 - skip; 4 - tail (balancing) rope; 5 - tensioner pulley; 6 - traction tensioner; 7 - frame; 8 - wedge; 9 - hydraulic cylinder; 10 - spring

\section{Conclusions}

The use of tensioning devices allows expanding the scope of application of hoists with friction pulleys at smaller depths with no artificial weighing of skips, increasing material consumption of the installation as a whole, further incrementing power of hoist engine and, as a consequence, maintaining general hoisting efficiency. The use of tensioning devices allows approaching the design of skips from the view of strength using lightweight materials.

The work of tensioning devices is more effective when the depth of the shaft does not exceed $800 \mathrm{~m}$.

The application of tensioning devices improves the design of skips from the view of strength with the use of lightweight materials, generally providing a significant reduction in the material intensity of the installation.

\section{References}

[1] Bezhok V.R., Dvornikov V.I., Manetz I.G., Pristrom V.A. Mine hoisting, Donetsk, South-East, 2007.

[2] Pesvianidze A.V. Calculation of mine hoisting facilities. Moscow, Nedra, 1992.

[3] Dimashko A.D., Gershnikov I.Ya., Krevnevich A.A. Electric mine winches and hoisting machines. Moscow, Nedra, 1972.

[4] Nesterov P.P., Shabanov-Kushnarenko Yu.P., Melentyev Yu.I. Expansion of the scope of application of multi-rope hoists due to installation of opposing pulleys. Izv. Universities. Mountain Journal, 1965, 4.

[5] Ivanov I.D. Multi-rope hoisting machines and features of their technical operation. Izv. Universities. Mountain Journal, 1971, 8. 
[6] Kabanov V.A., Factorovich A.M. Ways of expanding the scope of application of multi-rope mine hoists with friction pulleys. Izv. VUZov. Mining Journal, 1960, 7.

[7] Bykov V.L. Multi-rope hoisting installations with rope-guide pulleys for deep quarries. Izv. Universities. Mining Journal, 1968, 4.

[8] A.S. I02034I (USSR). Hoist installation / Production Association "Apatite"; Auth. invented S.S. Naumov. Appl. 07.06.81 No. 33I2I83 / 29-II; Publ. in BI, 1983, No. 20; MKI3 B 66 B 7/10.

[9] Naidenko I.S., Bely V.D. Mine multi-rope hoist. Moscow, Nedra, 1979.

[10] Naumov S.S. Development of schemes and devices for the expansion of the scope of multirope hoists. Thesis for the degree of candidate of technical sciences. Leningrad, Mining Institute, 1987.

[11] Kragelsky I.V., Vinogradova I.E. Friction coefficients: a reference book. Moscow, Mashgiz, 1955. $188 \mathrm{p}$. 